\title{
Identification, Prevalence and Use of Medicinal Plants in Fulbaria Upazila of Mymensingh District
}

\author{
M. U. Rashid ${ }^{1 *}$ and M. S. Eakram ${ }^{2}$ \\ ${ }^{1}$ Dept. of Agricultural Extension and Rural Development \\ Patuakhali Science and Technology University, Dumki, Patuakhali-8602 \\ ${ }^{2}$ Department of Agriculture Extension, Gaffargoan, Mymensingh \\ *Corresponding author and Email: murashidpstu@yahoo.com
}

\begin{abstract}
A study was carried out in Fulbaria Upazila under Mymensingh district covering 70 homesteads from three unions namely, Kaladaha, Enayetpur and Achim-patuli. Data were collected using interview schedule during 23 February to 10 April 2004. To identify the medicinal plants and their uses, a total of 30 medicinal plant species were recorded from the study area. The most prevalent species were Bashok (Adhatoda vasica), Neem (Azadirachta indica), Nishinda (Vitex negundo), Akonda (Calotropic gigantea) Pitraj (Amoora rohituka), Shialmutra (Blumea lacera), Apang (Achyranthes aspera) and Tulsi (Ocimum sanctum). The highest proportion $(48.57 \%)$ of the respondents reported about moderate use while 31.43 and $20.0 \%$ opined high and low use of medicinal plants, respectively. Correlation analysis revealed that among the selected characteristics of the farmers such as age, education, farm size, organizational participation, benefits received from medicinal plants, environmental awareness and knowledge about medicinal plants had significant relationship with the use of medicinal plants.
\end{abstract}

Key words: Medicinal plants, prevalence and use.

\section{Introduction}

Medicinal plants have a significant role in various traditional systems of medication such as Ayurvedic and Unanic medicine in different countries including Bangladesh. Medicinal plants still play an important role in developing countries of Asia, both in preventative and curative treatments, despite advances in modern western medicine. People of many Asian countries earn their livelihoods from selling collected material from the forest or from cultivation of medicinal plants on their own lands.

From the time immemorial, the people of Bangladesh traditionally and culturally are used to take medicinal plants mainly for cure against diseases and aesthetic usages. Until recently, most of the regions were rich in herbal medicinal resources. Unfortunately, these valuable resources have drastically been eroded in resent years due to biotic interferences, shrinking land resource base, deforestation, insufficient support from the government and public policies and lack of appropriate management and institutional structure.

Research on herbal medicinal plants and associate issues are limited in Bangladesh. Rashid et al. (1987) conducted a research on the nature and functional dynamics of crude drug market in Bangladesh. They observed that different Ayurvedic, Unani and other pharmaceutical industries of the country commonly used some 142 different crude drugs. Chawdhury et al. (1996) documented 42 folk 
formularies, which had traditionally been used against dysentery and diarrhoea in Bangladesh. Another study by Alam et al. (1996) also documented 143 folk formularies against 53 common diseases. Land scarcity in the country makes community forestry an important alternate system over traditional forestry because of its integrated approach and better management. In community forests medicinal plants can be an effective compatible agroforestry component. The present situation of rapidly growing population in the country is leading to over exploitation of natural resources causing irreparable damages and extinction of many valuable medicinal plant species.

Traditional medicinal plants in the past dealt with the health sector, but they are increasingly becoming the part of agriculture and even of environmental programmes. The global biodiversity strategy recognized the importance of conserving medicinal plants biodiversity. (WRI/IUCN/UNEP, 1992).

Unfortunately, many of our species are over exploited and will face extinction if they are not duly protected or cultivated. It was, therefore, a felt-need for field survey to assess the feasibility and prospects of initiation programme for conservation of medicinal plants. In view of the above considerations, the study was undertaken with the following objectives:

i) To identify the existing medicinal plant species, their diversity and benefits;

ii) To determine the extent of use of medicinal plants; and

iii) To explore the relationship of the selected characteristics of the respondents with their use of medicinal plants

\section{Methodology}

\subsection{Study area, population and sampling}

The study was conducted in Fulbaria Upazila under Mymensingh district during 2004. A total of six villages were selected from 17 villages, which were selected from three unions, namely Kaladaha, Enayetpur and Achim patuli of Fulbaria Upazilia. Fifteen \% respondents were selected randomly from a population of 670 . Thus, 70 farmers constituted the sample of the study. The data of this study were collected through interview schedule during 23 February to 10 April, 2004

\subsection{Measurement of prevalence of medicinal plants}

Prevalence of medicinal plants means general widespread existence of medicinal plants in a particular area. It is always measured as relative prevalence. Relative prevalence of medicinal plant species was determined as:

Relative prevalence $(\%)=\frac{\text { No. of particular medicinal plant species }}{\text { Total population of all medicinal plant species }} \times 100$

\subsection{Selection and measurement of independent and dependent variables}

A total of nine characteristics of farmers were selected namely age, education, family size, farm size, annual income, organizational participation, benefits received from medicinal plants, environmental awareness, knowledge about medicinal plants as independent variables. Most of the independent variables were measured by developing scales (Table 1). Use of medicinal plant by the respondents was the dependent variable.

Use of medicinal plant was measured on the basis of total number of species used by the farmers in different sectors such as against human diseases, animal diseases and as pesticide. A score of one (1) was given for every plant species for its use as follows:

\begin{tabular}{rc}
\hline Name of species used & Score assigned \\
\hline Species no 1 & 1 \\
Species no 2 & 1 \\
Species no 3 & 1 \\
\hline
\end{tabular}


Table 1. Relative prevalence of medicinal plant species grown in the study area.

\begin{tabular}{l|l|l|c}
\hline Sl no. & Common name & Scientific name & Relative prevalence (\%) \\
\hline 1 & Bashok & Adhatoda vasica & 16.28 \\
2 & Neem & Azadiracta indica & 14.12 \\
3 & Nishinda & Vitex negundo & 12.09 \\
4 & Akonda & Calotropic gigantea & 6.05 \\
5 & Pitraj & Amoora rohituka & 5.43 \\
6 & Shial mutra & Blumea lacera & 4.81 \\
7 & Apang & Achyranthes aspera & 4.03 \\
8 & Tulsi & Ocimum sanctum & 3.41 \\
9 & Thankuni & Hydrocotyle asiatica & 3.26 \\
10 & Shimul & Salmalion malabaricum & 3.25 \\
11 & Kanranga & Averrhoa carambola & 3.10 \\
12 & Khorajura & Lisea monopetala & 2.95 \\
13 & Motkila & Glycosmis pentaphylla & 2.79 \\
14 & Gulanchalata & Tinospora cordifolia & 2.33 \\
15 & Vat & Clerocendrum viscosum & 2.33 \\
16 & Bel & Aeyle mermelos & 2.33 \\
17 & Lazzaboti & Mimosa pudica & 1.39 \\
18 & Sajna & Moringa olefera & 1.24 \\
19 & Bishkatali & Persicria hydropiper & 1.24 \\
20 & Datura & Datura metel & 1.09 \\
21 & Patharkuchi & Kalanchoe pinnata & 1.09 \\
22 & Arjun & Terminalia arjuna & 1.08 \\
23 & Bishollakoruni & Polygonum gecumbern & 0.93 \\
24 & Agunsura & Cordylin terminalis & 0.78 \\
25 & Ishawar mul & Aristolochia indica & 0.62 \\
26 & Tezpata & Cinnamomum temala & 0.62 \\
27 & Ulotkombol & Abroma augusta & 0.47 \\
28 & Gangasagor & & 0.31 \\
29 & Chatian & Alstonia scholaris & 0.31 \\
30 & Bohera & Terminalia belerica & 0.31 \\
\hline & & & $N$ \\
\end{tabular}

\section{Results and Discussion}

\subsection{Identification of medicinal plants}

In the study area, a total of 30 species of medicinal plants were identified (Table1). The dominating plant species were Bashok, Neem, Nsisindha, Akonda, Pitraj, Shialmutra, Apang, Tulsi and Thankuni. In the study area most threatened species were Tejpata, Ulotkombol, Gongasagor, Chatian and Bohera.

\subsection{Prevalence}

The relative prevalence of medicinal plants has been shown in (Table1). The highest prevalent species in the study area were Bashok (16.28\%) followed by Neem (14.12), Nishindha (12.09), Akonda (6.05) and Pitraj (5.43). These species were found in almost all the farm categories probably due to ecological and physiographic factors. There was minor difference in relative prevalence of less common species. This might be due to the differences in physiographic factors, soil characteristics and using habit of farmers in the study area.

\subsection{Selected characteristics of the farmers}

Characteristics of the respondents are depicted in Table 2. Data contained in Table 2 indicate that majority of the farmers were middle aged (64.28 $\%$ ) and highest proportion (45.71\%) of them had primary level of literacy. 
Table 2. Salient features of the farmer's selected characteristics.

\begin{tabular}{|c|c|c|c|c|c|c|c|c|}
\hline \multirow{2}{*}{$\begin{array}{l}\text { Selected } \\
\text { characteristics }\end{array}$} & \multirow[t]{2}{*}{ Categories } & \multicolumn{2}{|c|}{ Respondents } & \multirow{2}{*}{$\begin{array}{l}\text { Measurement } \\
\text { scale/unit }\end{array}$} & \multicolumn{2}{|c|}{ Range } & \multirow[t]{2}{*}{ Mean } & \multirow{2}{*}{$\begin{array}{l}\text { Std. } \\
\text { Devi. }\end{array}$} \\
\hline & & No. & $\%$ & & Min. & Max. & & \\
\hline \multirow[t]{3}{*}{ Age } & Young aged (25-43) & 11 & 15.71 & \multirow{3}{*}{ Year } & \multirow{3}{*}{25} & \multirow{3}{*}{73} & \multirow{3}{*}{54.54} & \multirow{3}{*}{10.48} \\
\hline & Middle aged (44-64) & 45 & 64.28 & & & & & \\
\hline & Old age (65-73) & 14 & 20.0 & & & & & \\
\hline \multirow[t]{4}{*}{ Education } & Illiterate & 25 & 35.71 & \multirow{4}{*}{$\begin{array}{c}\text { Year of } \\
\text { schooling }\end{array}$} & \multirow{4}{*}{0.00} & \multirow{4}{*}{14.00} & \multirow{4}{*}{4.46} & \multirow{4}{*}{4.17} \\
\hline & Primary level & 32 & 45.71 & & & & & \\
\hline & Secondary level & 12 & 17.14 & & & & & \\
\hline & Above secondary & 1 & 1.43 & & & & & \\
\hline \multirow[t]{3}{*}{ Family size } & Small (2-4) & 16 & 22.85 & \multirow{3}{*}{$\begin{array}{l}\text { Number of } \\
\text { members }\end{array}$} & \multirow{3}{*}{2.00} & \multirow{3}{*}{19.00} & \multirow{3}{*}{7.34} & \multirow{3}{*}{3.68} \\
\hline & Medium (5-10) & 38 & 54.28 & & & & & \\
\hline & Large(11-19) & 16 & 22.85 & & & & & \\
\hline \multirow[t]{5}{*}{ Farm size } & Landless( upto 0.2 ha) & 6 & 8.57 & \multirow{5}{*}{ Hectare } & & & & \\
\hline & $\operatorname{Marginal}(0.21-0.60)$ & 12 & 17.14 & & & & & \\
\hline & Small (0.61-1.0 ha) & 22 & 31.43 & & 0.00 & 2.43 & 0.924 & 0.573 \\
\hline & Medium (1.01-2 ha) & 25 & 35.71 & & & & & \\
\hline & Large ( above $2.0 \mathrm{ha}$ ) & 5 & 7.14 & & & & & \\
\hline Annual & Low-income (10-29) & 11 & 15.71 & Thourand & & & & \\
\hline income & Medium income(30-99) & 37 & 52.86 & ('000’) Taka & 0.00 & 0.78 & 0.172 & 0.129 \\
\hline & High income(100-280) & 22 & 31.43 & & & & & \\
\hline Organizational & No participation(0) & 16 & 22.86 & & & & & \\
\hline participation & Low participation(up to 1 ) & 17 & 24.29 & scaling & 0.00 & 3.00 & 1.47 & 1.03 \\
\hline & Medium participation(1.1-2) & 25 & 35.71 & & & & & \\
\hline & High participation(up to 3) & 12 & 17.14 & & & & & \\
\hline Benefits & $\operatorname{Low}(0.00-0.05)$ & 11 & 15.71 & Thousand & & & & \\
\hline received from & $\operatorname{Medium}(0.06-0.24)$ & 48 & 68.57 & ('000’ ) Taka & 0.00 & 0.78 & 0.172 & 0.129 \\
\hline & $\operatorname{High}(0.25-0.78)$ & 11 & 15.71 & & & & & \\
\hline Environmental & $\operatorname{Low}(0.00-0.05)$ & 32 & 45.71 & & & & & \\
\hline awareness & Medium (6.0-16.0) & 25 & 35.71 & Score & 0.00 & 24.0 & 9.31 & 7.87 \\
\hline & $\operatorname{High}(17.0-24.0)$ & 13 & 18.57 & & & & & \\
\hline Knowledge & Low $(0.00-2.0)$ & 26 & 37.14 & & & & & \\
\hline about & Medium(3.0-5.0) & 25 & 35.71 & Score & 0.00 & 8.00 & 3.76 & 2.62 \\
\hline medi.plants & $\operatorname{High}(6.0-8.0)$ & 19 & 27.14 & & & & & \\
\hline Uses of & $\operatorname{Low}(6-9)$ & 14 & 20.00 & & & & & \\
\hline medicinal & Medium (10-12) & 34 & 48.57 & Score & 6.00 & 15.00 & 11.29 & 2.15 \\
\hline plants & $\operatorname{High}(13-15)$ & 22 & 31.43 & & & & & \\
\hline
\end{tabular}


Table 3. Correlation between the dependent and independent variables.

\begin{tabular}{|c|c|c|c|}
\hline $\begin{array}{l}\text { Sl. } \\
\text { No. }\end{array}$ & Dependent variable & Independent variable & $\begin{array}{l}\text { Calculated ' } r \text { ' } \\
\text { value }\end{array}$ \\
\hline 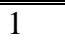 & & Age & $0.317 * *$ \\
\hline 2 & & Education & $0.249 *$ \\
\hline 3 & & Family size & $0.009^{\mathrm{NS}}$ \\
\hline 4 &.$\Xi$ & Farm size & $0.289 *$ \\
\hline 5 & $\stackrel{0}{7}$ & Annual income & $0.175^{\mathrm{NS}}$ \\
\hline 6 & $\stackrel{\Xi}{g}$ & Organization participation & $0.298 *$ \\
\hline 7 & $\ddot{0} \cong$ & Benefits received from medicinal plants & $0.271 *$ \\
\hline 8 & $\triangleq \tilde{\Xi}$ & Environmental awareness & $0.325 * *$ \\
\hline 9 & 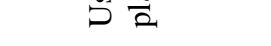 & Knowledge about medicinal plants & $0.401 * *$ \\
\hline
\end{tabular}

*Significant at $\mathrm{p}<0.05$; **Significant at $<0.01 ; \mathrm{NS}=$ Non significant

Medium sized family was dominant in the locality. Majority of the farmers $(67.14 \%)$ had small to medium size farm, $22 \%$ respondents belonged to the high income group, while $37 \%$ respondents belonged to medium income group. One third of the respondents had medium participation in organization followed by 24.29 $\%$ low participation. Majority of the farmers $(68.57 \%)$ received medium benefit from medicinal plants. About half of the respondents $(45.71 \%)$ had low environmental awareness followed by $35.71 \%$ medium and $15.71 \%$ high environmental awareness. Major proportion of the respondents had medium $(35.71 \%)$ to low $(37.14 \%)$ knowledge about medicinal plants.

The score for use of medicinal plants ranged from 6 to 15 with an average of 11.29 and standard deviation 2.15. Based on the score of use, the respondents were classified into three categories namely, low use (6-9), medium use (10-12) and high use (13-15). Table 2 reveals that about half of the respondents belonged to the medium use category, while $20 \%$ were in low use category and $31.43 \%$ in high use category.

\subsection{Relationship between the selected characteristics of farmers and their use of medicinal plants}

Age, education, farm size, organizational participation, benefits received from medicinal plants, environmental awareness and knowledge about medicinal plants had positive significant relationship with the use of medicinal plants. In many social researches, age does not show any significant effect on the concerned variable. However, in the present study, the age of the respondents had positive significant relationship with use of medicinal plants. It may be due to the fact that the aged people know much more than the youngers about medicinal value of plant from their experience, and they also saw their ancestors to use medicinal plants as in those days synthetic chemicals were not so available.

\section{Conclusions}

About 30 species of medicinal plants are normally used by the people in the study area. Among them Bashok, Neem, Nishindha, Akonda, Pitraj, Shialmutra and Apang are the most prevailing species. On the basis of prevalence score, Bashok, Neem, Nishindha, Akonda, Pitraj, Shialmutra and Apang are consecutively the most prevailing species. Among the identified species, Bashok, Neem, Nishindha, Akonda, Pitraj and Tuslshi are specially used in national and international pharmacopoeia. Most of the farmers showed medium to high use of medicinal plants. Out of nine selected characteristics age, education, farm size, organizational participation, benefits received from medicinal plants, environmental awareness and knowledge about medicinal plants played significant role in the use of medicinal plants. 


\section{References}

Alam, M. K., Chawdhury, J. U., and Hasan, M. A. 1996. Some Folk Formularies from Bangladesh. Bangladesh Journal of Life Science, 8191):49-69.

Chawdhury, J. U., Alam, M. K., and Hassan, M. A.1996. Some Traditional Folk Formulation Aginst Dysentry and Diarrhoeain Bangladesh. Journal of Economic and Textile Botany. 12:20-23.
Rashid, M. H., Alam. M. J., Ara, R., and Merry, S. R.1987. Crude Drug Market Survey, Bangladesh. Bangladesh Forest Research Inst. Chittagong (Unpublished)

WRI/IUCN/UNEP.1992. Global Biodiversity. World Conserv. Monito. Cent. Cambridge, UK. 